\title{
Efektivitas Sidang Keliling (Studi di Pengadilan Agama Wonogiri)
}

\author{
Muhammad Latif Fauzi
}

\begin{abstract}
The Effectiveness of Mobile Courts (The Case in Wonogiri Religious Courts). This article examines the mobile court policy implemented by the Wonogiri Religious Court. The aim is to find out the effectiveness of the mobile court carried out in expanding access to the justice seekers, especially women. Using the step-by-step theory developed by Rolax, the researcher observes the practices of mobile session conducted by PA Wonogiri around the districts of Puwantoro and Baturetno, about $40 \mathrm{~km}$ away from the Wonogiri Religious Courts Office. The study finds out that, judging from the formal procedural aspect, the mobile courts do have a relatively important role in the expansion of people's access to justice, especially for women, This expansion of access is more meaningful as an effort to provide assistance to the parties so that the time, cost, and energy they spend to attend the session could be more efficient and economical.
\end{abstract}

Keywords: mobile courts, access to justice, religious courts, Wonogiri

Abstrak: Efektivitas Sidang Keliling (Studi di Pengadilan Agama Wonogiri). Artikel ini menelaah kebijakan Sidang Keliling yang dilaksanakan oleh Pengadilan Agama Wonogiri. Tujuannya adalah untuk mengetahui sejauh mana efektivitas sidang keliling yang dilaksanakan itu dalam memperluas akses kepada masyarakat pencari keadilan terutama kaum perempuan. Dengan menggunakan teori steps to justice yang dikembangkan oleh Rolax, peneliti mencoba mengamati praktik Sidang Keliling yang dilaksanakan oleh PA Wonogiri di sekitar kecamatan Puwantoro dan Baturetno yang berjarak sekitar 40 Km jauhnya dari Kantor Pengadilan Agama Wonogiri. Studi ini menemukan bahwa, jika dilihat dari aspek prosedur formal, sidang keliling memang memiliki peran yang relatif penting dalam perluasan akses masyarakat, terutama kaum perempuan, terhadap keadilan. Perluasan akses ini lebih dimaknai sebagai upaya memberi bantuan kepada para pihak agar waktu, biaya, dan tenaga yang mereka keluarkan untuk menghadiri sidang lebih hemat dan efisien.

Kata Kunci: sidang keliling, akses terhadap keadilan, Pengadila Agama, Wonogiri

Pengajar Fakultas Syari'ah, Institut Agama Islam Negeri Surakarta

Jalan Jl. Pandawa, Dusun IV, Pucangan, Kartasura, Kabupaten Sukoharjo, Jawa Tengah 57168

E-mail: muhlatiffauzi@gmail.com 


\section{Pendahuluan}

Sejak reformasi bergulir pada tahun 1998, lembaga peradilan di bawah kendali Mahkamah Agung (MA)dinilai telah melakukan reformasi kelembagaan secara progresif. ${ }^{1}$ Pada tahun 2003, MA mengeluarkan Cetak Biru Pembaruan yang secara umum berkaitan dengan reformasi birokrasi dan administrasi. ${ }^{2}$ Secara spesifik, reformasi ini mendorong perubahan pada beberapa hal kunci, seperti transparansi putusan, manajemen sistem informasi teknologi, dan kode etik hakim. ${ }^{3}$

Di sisi lain, terdapat desakan yang cukup kuat baik dari lembaga internasional di bidang perempuan maupun organisasi masyarakat sipil, agar lembaga peradilan melakukan penguatan akses terhadap keadilan (access to justice). Termasuk dalam dinamika ini, peradilan agama dituntut sebagai badan peradilan yang tidak semata-mata menerapkan hukum tetapi juga menegakkan hukum untuk memenuhi kebutuhan para pencari keadilan dan masyarakat pada umumnya yang selalu berubah dan berkembang. ${ }^{4}$

${ }^{1}$ Sejarah dan wilayah pembaruan yang dilakukan oleh peradilan agama, di bawah komando Dirjen Badilag, telah digambarkan oleh Cate Sumner dan Tim Lindsey, Courting Reform: Indonesia's Islamic Courts and Justice for the Poor (Australia: Lowy Institute for International Policy, 2010). Lihat juga Janedjri M Gaffar. "Kedudukan, Fungsi dan Peran Mahkamah Konstitusi dalam Sistem Ketatanegaraan Republik Indonesia." Jurnal Mahkamah Konstitusi, Jakarta (2009). Sebastiaan Pompe. Runtuhnya Institusi Mahkamah Agung. Lembaga Kajian dan Advokasi untuk Independensi Peradilan, 2012.

${ }^{2}$ Mahkamah Agung, Cetak Biru Pembaruan Peradilan 2010-2035 (Jakarta: MA RI, 2010), h. 35.

${ }^{3}$ Terkait beberapa hal tersebut bisa dilihat dalam karya Nunuk Nuswardani. "Upaya Peningkatan Kualitas Putusan Hakim Agung dalam Mewujudkan Law and Legal Reform." Jurnal Hukum Ius Quia Iustum 16, no. 4 (2009): h. 515-532. Desi Fernanda. "Paradigma New Public Management (NPM) Sebagai Kerangka Reformasi Birokrasi Menuju Kepemerintahan yang Baik (Good Governance) di Indonesia." Jurnal Borneo Administrator 2, no. 3 (2006). Ahmad Basuki. "Pengawasan Terhadap Penyelenggaraan Kekuasaan Kehakiman Sebagai Upaya dalam Mewujudkan Akuntabilitas Peradilan Pidana.” Perspektif 18, no. 1 (2013): h. 56-63. Desy Meutia Firdaus. "Reorientasi Konsep Kekuasaan Kehakiman dan Implikasinya Terhadap Kedudukan Mahkamah Agung dalam Sistem Peradilan Pidana di Indonesia." PhD diss., Program Pasca Sarjana Universitas Diponegoro, 2001. Kamaruddin. "Diskursus Penyatuatapan Peradilan Agama di Bawah Mahkamah Agung (Studi Hukum Responsif).” Al-'Adl 8, no. 1 (2015): h. 56-72. Samsul Wahidin. "Hakim Agung Sebagai Agent Of Change Menuju Law and Legal Reform." Jurnal Cakrawala Hukum 5, no. 2 (2014): h. 157-167. Hasbi Hasan. "Dinamika Yurisprudensi Mahkamah Agung dalam Bidang Perdata Islam.” Journal de Jure 3, no. 2 (2011). M. Nur Sholikin. "Perbaikan Prosedur Pengujian Peraturan Perundang-Undangan di Mahkamah Agung." Jurnal Hukum dan Peradilan 3, no. 2 (2014): h. 149-162.

${ }^{4}$ Salah satu lembaga donor internasional yang mendorong reformasi peradilan agama 
Menjadi set up dari Peradilan Agama itu, ialah modernisasi peradilan agama dalam rangka pemantapan struktur peradilan di Indonesia. Selain tugas utama peradilan agama adalah mengatur bekerjanya pengadilan, maka akan dijumpai ketentuan-ketentuan yang mengatur tentang wilayah kekuasaan yang bersifat prosedural, seperti memeriksa dan mengadili orang-orang yang beragama Islam, mendamaikan dan atau mengadili, dalam bidang-bidang perkara tertentu. ${ }^{5}$

Pada tahun 2007, Cate Sumner, difasilitasi oleh Indonesia-Australia Legal Development Facility (IALDF), melakukan survei terkait akses dan kesetaraan dalam peradilan agama (religious court access and equity survey). Penelitian yang menguji sejauh mana hukum dan keadilan yang diberikan peradilan agama telah dirasakan masyarakat (terutama yang tinggal di pedesaan) ini menyajikan temuan penting dan menarik. Terdapat $71,1 \%$ dari 1.000 responden penelitian yang bersedia untuk menggunakan kembali jasa Pengadilan Agama, selanjutnya disebut PA, di masa depan, jika mereka mengalami masalah hukum yang sama. ${ }^{6}$ Menurut Sumner dan Lindsey, harapan untuk kembali menggunakan PA ini tidak sesederhana karena disebabkan yuridiksi peradilan agama menuntut agar semua persoalan (percekcokan) dalam rumah tangga, seperti perceraian, diselesaikan melalui mekanisme pengadilan. Tingginya angka tersebut justru menunjukkan pilihan sadar dan ekspresi kepuasan masyarakat terhadap layanan PA. Keinginan mereka untuk kembali dapat diartikan sebagai pengakuan atas pentingnya posisi lembaga PA dalam memberikan kepastian hukum agar masyarakat dapat mengakses hak dan keadilan dari negara yang lain. ${ }^{7}$

adalah The Asia Foundation melalui program Peningkatan akses perempuan terhadap keadilan di Indonesia. Area dari program ini mulai dari peningkatan kapasitas hakim dalam analisis gender terapan, pelatihan mediasi, dan promosi pengalaman terbaik (best practice) dan partisipasi publik. The Asia Foundation, "Religious Courts: Improving Women's Access to Justice in Indonesia," profil program, 2007.

${ }_{5}^{5}$ H.A. Khisni, "Peradilan Agama Sebagai Peradilan Keluarga Serta Perkembangan Studi Hukum Islam di Indonesia”, Jurnal Hukum Universitas Sultan Agung 25, no. 1, (2011): h. 492.

${ }^{6}$ Cate Sumner, "Providing Justice for the Justice Seeker: A Report on the Indonesian Religious Courts, Access and Equality Study - 2007, Summary of Research Findings,” 2007, survei oleh IALDF, UIN Jakarta dan Yogyakarta, PEKKA NGO, the Family Court of Australia, dan Mahkamah Agung.

${ }^{7}$ Cate Sumner dan Tim Lindsey, Courting Reform: Indonesia's Islamic Courts and Justice 
Tingkat kepuasan masyarakat di atas ternyata tidak berbanding lurus dengan persoalan keuangan untuk membiayai semua pengeluaran dari mulai pendaftaran perkaran sampai perkara selesai. Penelitian Sumner menemukan bahwa pengguna Pengadilan Agama memiliki rata-rata pendapatan tiga kali lebih di atas standard garis kemiskinan Rp. 146.837 per bulan bagi yang tinggal di pedesaan, atau Rp. 187.942 per bulan yang hidup di wilayah perkotaan. Rata-rata pendapatan bulanan per kapita bagi pengguna pengadilan berjenis kelamin perempuan sekitar 75\% dari pengguna pengadilan laki-laki, yaitu Rp.834.912 per bulan untuk perempuan dibandingkan dengan Rp. 1.106.221 untuk laki-laki. Jika satu perkara di PA biasanya selesai dalam waktu tiga bulan dan membutuhkan waktu perjalanan ke PA sebanyak tiga kali, maka rata-rata biaya total yang dikeluarkan untuk menyelesaikan satu perkara tersebut adalah Rp. 789.666.

Beban biaya ini ternyata sangat berat bagi pengguna perempuan, terutama mereka yang tergolong PEKKA. PEKKA adalah perempuan yang menjadi kepala keluarga akibat meninggalnya suami, perceraian, ditinggal, melajang atau menikah namun bertanggung jawab atas penghidupan rumah tangga (karena suaminya sakit, atau tidak mampu bekerja, atau bekerja di luar negeri dan tidak memberi dukungan keuangan pada keluarga). Karena letak PA biasanya di tengah kota, sedangkan sebagian besar mereka tinggal di pedesaan, jarak yang ditempuh untuk mencapai PA lebih dari $20 \mathrm{~km}$. Untuk biaya perjalanan ke dan dari PA, mereka harus membayar sekitar 26\% dari pendapatan rumah tangga bulanan per kapita. Fakta ini juga tidak banyak memberi pilihan bagi lembaga peradilan, kecuali untuk peningkatan akses perempuan terhadap keadilan.

Akses terhadap keadilan, merujuk pada definisi yang dibuat oleh United Nation Development Program (UNDP), adalah kemampuan seseorang untuk mencari dan memperoleh keadilan melalui lembaga hukum dan keadilan negara maupun non-negara sejalan dengan prinsipprinsip hak asasi manusia. ${ }^{8}$ Pengertian ini dikembangkan oleh Van

for the Poor, h. 30-32. Baca juga Tim Lindsey dan Cate Sumner, "Indonesia: Islamic Courts as Governance Institutions," East Asia Forum Quarterly 3, no. 1 (Maret 2011): h. 24-25.

${ }^{8}$ UNDP, Justice for All? An Assessment of Access to Justice in Five Provinces of Indonesia 
Vollenhoven Institute (VVI) dengan mensyaratkan adanya kapasitas, termasuk pengetahuan hukum, yang harus dimiliki oleh pencari keadilan agar persoalan mereka dapat didengar dan memperoleh layanan hukum dari lembaga negara atau non-negara. ${ }^{9}$ Konsep ini sejatinya mengajukan gagasan dasar agar warga negara dan semua kalangan mampu mencapai keadilan sosial (social justice). ${ }^{10}$

Untuk memperkuat akses masyarakat terhadap keadilan ini, peradilan agama telah melakukan beberapa upaya, seperti sidang keliling (circuit court), ${ }^{11}$ sidang perkara prodeo (perkara dengan pembayaran cuma-

(Jakarta: UNDP, 2007).Lihat juga Van Vollenhoven Institute, “The reseach scheme," t.t., http:// law.leiden.edu/organisation/metajuridica/vvi/research/access-to-justice/access-to-justice/the-concept. html. Baca juga Dewi Novirianti, "Female Migrant Workers and Access to Justice Case Study ofDistrict Legislation in Cianjur," Van Vollenhoven Institute, 2009. Dewi Novirianti, "Akses Perempuan terhadap Keadilan: Mekanisme Hukum dan Keadilan, Peranan Pendamping, dan Rasa Keadilan Korban," 5 Januari 2011, www.komnasperempuan.or.id. Sulistyowati Irianto, Henky Irzan, Lim Sing Meij, Theresia Dyah Wirastri, Tirtawening Parikesit, Titiek Kartika, dan Vidhyandika D. Perkasa. Akses Keadilan dan Migrasi Global: Kisah Perempuan Indonesia Pekerja Domestik di Uni Emirat Arab. Yayasan Pustaka Obor Indonesia, 2011. Indro Sugianto. Class Action: Konsep dan Strategi Gugatan Kelompok Untuk Membuka Akses Keadilan bagi Rakyat. Setara Press, 2013. Sulistyowati Irianto. Perempuan dan Hukum: Menuju Hukum yang Berperspektif Kesetaraan dan Keadilan: 22 Tahun Konvensi CEDAW di Indonesia. Yayasan Obor Indonesia, 2006. Yos Johan Utama. "Menggugat Fungsi Peradilan Tata Usaha Negara Sebagai Salah Satu Akses Warga Negara Untuk Mendapatkan Keadilan dalam Perkara Administrasi Negara." (2007). Bassina Farbenblum, Eleanor Taylor-Nicholson, dan Sarah Paoletti. Akses Buruh Migran Terhadap Keadilan di Negara Asal: Studi Kasus di Indonesia. Open Society Foundations, 2013. Ward Berenschot, Adriaan Bedner, E. Laggut-Terre, dan D. Novrianti. "Akses Terhadap Keadilan: Perjuangan Masyarakat Miskin dan Kurang Beruntung Untuk Menuntut Hak di Indonesia." (2011). Agus Raharjo, A. Angkasa, dan Rahadi Wasi Bintoro. "Akses Keadilan Bagi Rakyat Miskin (Dilema dalam Pemberian Bantuan Hukum oleh Advokat)." Mimbar Hukum-Fakultas Hukum Universitas Gadjah Mada 27, no. 3 (2015): h. 432-444. Mahrita Aprilya Lakburlawal. "Akses Keadilan Bagi Masyarakat Adat dalam Penyelesaian Sengketa Tanah Ulayat yang Diberikan Hak Guna Usaha." Jurnal Hukum Acara Perdata ADHAPER 2, no. 1 (2016): h. 59-75. Adriaan Bedner, Ward Berenschot, Eddie Riyadi Laggut-Terre, dan Dewi Novirianti. "Akses Terhadap Keadilan: Perjuangan Masyarakat Miskin dan Kurang Beruntung Untuk Menuntut Hak di Indonesia.” Jakarta: HuMa-Jakarta, Van Vollenhoven Institute, Leiden University, KITLV-Jakarta: Epistema Institute (2011).

${ }^{9}$ Adriaan Bedner dan Jaqueline Vel, "An Analytical Framework for Empirical Research on Access to Justice," Law, Social Justice \& Global Development (An Electronic Law Journal) 1 (2010): h. 2-29.

${ }^{10}$ Kelompok Kerja Akses terhadap Keadilan, Strategi Nasional Akses terhadap Keadilan (Jakarta: Kementerian Bappenas, 2009).

${ }^{11}$ Tulisan terkait sidang keliling (circuit court) dapat dilihat pada beberapa karya tulis seperti Thalis Noor Cahyadi. "Efektifitas Pos Bantuan Hukum di Pengadilan (Studi Pada Posbakum Pengadilan Agama Sleman Tahun 2011-2012).” Jurnal Rechts Vinding: Media Pembinaan Hukum Nasional 2, no. 1 (2013): h. 17-30. Sofiani Hartatik. "Analisis Yuridis Terhadap Pelaksanaan Sidang Keliling Itsbat Nikah: Studi Kasus Pengadilan Agama Kabupaten Malang.” PhD diss., UIN Sunan Ampel Surabaya, 2014. M. Amin Syaefuddin. "Efektifitas Peran Sidang Keliling 
cuma), dan penyediaan pos bantuan hukum (posbakum). ${ }^{12}$ Pada tahun 2008, anggaran secara keseluruhan untuk peradilan agama dinaikkan menjadi 23 milyar rupiah (3 juta \$US), sedangkan di tahun 2009 anggaran yang diberikan sebesar 12 milyar (1,5 juta \$US). Khusus untuk alokasi sidang keliling, berdasarkan laporan Mahkamah Agung, pada tahun 2011, anggaran sekitar 3,5 milyar rupiah telah digunakan untuk menyelenggarakan sidang keliling atas 17.516 perkara oleh 321 PA. Sedangkan pada tahun 2012, sidang keliling atas 13.764 perkara oleh 264 PA dengan total biaya sekitar 2,8 milyar rupiah telah diselenggarakan. ${ }^{13}$ Penguatan akses terhadap keadilan melalui sidang keliling ini didasarkan pada argumen bahwa banyak sekali pencari keadilan yang memiliki keterbatasan akses, terutama transportasi, ke PA. Mereka umumnya tinggal di daerah pedesaan. Di Kabupaten Ciamis misalnya, jarak antara satu kecamatan ke PA dapat mencapai $60-90 \mathrm{~km} .{ }^{14}$

Terkait dengan sidang keliling tersebut, PA Wonogiri ${ }^{15}$ merupakan salah

Terhadap Asas Sederhana, Cepat, dan Biaya Ringan di Pengadilan Agama Pasuruan tahun 2011.” PhD diss., Universitas Islam Negeri Maulana Malik Ibrahim, 2012. Hazar Kusmayanti, Eidy Sandra, dan Ria Novianti. "Sidang Keliling dan Prinsip-Prinsip Hukum Acara Perdata: Studi Pengamatan Sidang Keliling di Pengadilan Agama Tasikmalaya." Jurnal Hukum Acara Perdata ADHAPER 1, no. 2 (2015): h. 101-116. Nor Rofi'i. "Analisis Hukum Acara Terhadap Pelaksanaan Sidang Keliling (Study Kasus Sidang Keliling di Pengadilan Agama Tanjung Balai Karimun di Kecamatan Kundur).” PhD diss., Universitas Islam Negeri Sultan Syarif Kasim Riau, 2015. Ulfi Azizah. "Analisis Hukum Acara Pelaksanaan Sidang Keliling (Studi Kasus Sidang Keliling di Pengadilan Agama Mungkid)." PhD diss., IAIN Walisongo, 2013. Muh Chamanda. "Efektifitas Sidang Keliling Kaitannya dengan Asas Sederhana, Cepat, dan Biaya Ringan (Studi Kasus di Pengadilan Agama Sungguminasa Kelas 2B Tahun 2013-2015).” PhD diss., Universitas Islam Negeri Alauddin Makassar, 2016.

${ }^{12}$ Rahmat Arijaya, "Access to Justice for Women: The Role of the Religious Courts," 28 Juni 2010.

${ }^{13}$ Data diolah dari Rekapitulasi Pelaporan dalam laman SMS Gateway Mahkamah Agung, t.t., http://sms.mahkamahagung.go.id/index.php/info/rekap.

${ }^{14}$ Rahmat Arijaya, "Access to Justice for Women: The Role of the Religious Courts," h. 9.

${ }^{15}$ Terkait penelitian atau tulisan yang membahas Pengadilan Agama Wonogiri adalah Anggit Kurniawan. "Tinjauan Yuridis Dispensasi Permohonan Nikah Bagi Anak di Bawah Umur (Studi Kasus Penetapan Pengadilan Agama Wonogiri).” PhD diss., Universitas Muhammadiyah Surakarta, 2014. Ekawati Mulyaningsih. "Pertimbangan Hakim dalam Pemberian Izin Poligami Menurut Undang-Undang Nomor 1 Tahun 1974 Tentang Perkawinan dan Peraturan Pemerintah Nomor 9 tahun 1975 Tentang Pelaksanaan Undang-Undang Perkawinan di Pengadilan Agama Wonogiri (Studi Kasus Perkara Nomor 515/pdt. g/2000/pa. wng).” PhD diss., Universitas Sebelas Maret, 2010. Arina El Haque Mafazatin. "Analisis Hukum Islam Terhadap Permohonan Talak Sebab Murtad (Telaah Putusan Pengadilan Agama Wonogiri Nomor: 0080/Pdt. G/2013/ PA. Wng dan Nomor: 0838/Pdt. G/2009/PA. Wng)." PhD diss., UIN Walisongo, 2014. Endarwati. "Gugatan Cerai dengan Alasan Menolak Dipoligami (Studi Kasus di Pengadilan 
satu dari sekian banyak institusi peradilan agama yang mendapat dukungan dana relatif besar dengan jumlah sidang keliling lebih banyak. Sidang keliling oleh PA Wonogiri diselenggarakan untuk pencari keadilan yang tinggal di sekitar kecamatan Puwantoro dan Baturetno. Jarak dua kecamatan tersebut ke PA Wonogiri sekitar $40 \mathrm{~km}$. Pada tahun 2011, PA Wonogiri menggelar 127 sidang keliling, sedangkan di tahun 2012, 50 sidang keliling. ${ }^{16}$

Penelitian ini akan menguji sejauh mana sidang keliling yang dilaksanakan PA Wonogiri telah mampu memperkuat akses terhadap keadilan, terutama perempuan yang memiliki keterbatasan untuk menyelesaikan persoalan keperdataannya melalui lembaga peradilan.

\section{Sidang Keliling dan Akses terhadap Keadilan}

Pengertian akses terhadap keadilan (acces to justice) dapat diartikan sebagai kesempatan atau kemampuan setiap warga negara tanpa membedakan latar belakangnya (ras, agama, keturunan, pendidikan, atau tempat lahirnya) untuk memperoleh keadilan melalui lembaga peradilan. Akses terhadap keadilan adalah hak setiap orang untuk mendapatkan akses memperoleh keadilan melalui lembaga peradilan yang merupakan hak asasi manusia. ${ }^{17}$

Terkait dengan relasi antara sidang keliling, akses terhadap keadilan, dan penegakan supremasi hukum (the rule oflaw), Bedner mengklasifikasi adanya dua arus utama pendekatan terhadap hukum/keadilan, yaitu pendekatan hukum formal dan hukum substantif. Merujuk pada pendapat para pakar tentang klasifikasi dua pendekatan (elemen) ini, Bedner menunjukkan perbedaan antara keduanya:

"Formal versions are concerned with law as an instrument and a basis of government, but are silent on what the law should regulate. Substantive versions, on the other hand, set standards to the contents of a norm, which should be morally justified... "18

\footnotetext{
Agama Wonogiri).” PhD diss., Universitas Muhammadiyah Surakarta, 2008.

${ }^{16}$ Data diperoleh dari laporan sidang keling PA Wonogiri tahun 2011 dan 2012 yang dipublikasi dalamt.t., http://pa-wonogirikab.go.id/laporan/detail/sidang-keliling.

${ }^{17}$ Anggung Malinda, Eka Nur Fitriana, dan M. Yasin al Arif, "Bantuan Hukum Terhadap Kaum Difabel Korban Tindak Pidana Upaya Mewujudkan Acces to Justice", Jurnal Hukum Ius Quia Iustum 21, No. 3, (Juli 2014): h. 472.

${ }^{18}$ Adriaan Bedner, "An Elementary Approach to the Rule of Law," Hague Journal on the
} 
Lebih lanjut, Bedner menguraikan perbedaan dua pendekatan di atas dengan merinci beberapa elemen yang tercakup oleh masingmasing pendekatan. Kategori pertama, pendekatan formal atau elemen prosedural melingkupi beberapa indikator, yaitu aturan hukum, aktivitas pemerintahan tunduk pada hukum, legalitas formal, dan demokrasi. Kategori kedua, pendekatan substantif meliputi beberapa elemen, yaitu ketundukan sistem dan tafsir hukum pada prinsip-prinsip dasar keadilan, perlindungan terhadap hak dan kebebasan individu, pemberian prioritas pada hak sosial, dan perlindungan atas hak kelompok. Bedner menambah kategori ketiga, yaitu mekanisme kontrol yang terdiri dari dua elemen: institusi kehakiman yang independen dan adanya lembaga lain (non negara) yang turut menjaga tegaknya aturan hukum. ${ }^{19}$

Meningkatnya akses terhadap keadilan khususnya bagi perempuan dapat diukur dari sejauh mana perempuan yang mencari keadilan tersebut telah melalui proses naming, blaming, dan claiming. Naming merupakan tahapan dimana perempuan mampu merasa dan menyadari atas ketidakadilan terjadi pada dirinya. Blaming merupakan posisi perempuan saat mereka memiliki keberanian sikap untuk menuntut orang atau pihak yang melakukan kekerasan terhadapnya, sedangkan claiming adalah tahap dimana perempuan memiliki daya atau akses untuk melapor dan mengadu kasus yang dialaminya kepada pihak ketiga. Ide tentang bagaimana cara untuk mendapatkan keadilan termasuk dalam tahap ini. ${ }^{20}$

Berikut dipaparkan secara lebih rinci tentang langkah-langkah, berdasarkan model Rolax, untuk menuju tercapainya keadilan hukum dan sosial.

Rule of Law 2, 2010, h. 54.

${ }^{19}$ Adriaan Bedner, h. 56-70.

${ }^{20}$ Penjelasan lebih lengkap tentang kerangkan analisis penelitian tentang akses terhadap keadilan dapat dibaca dalam Adriaan Bedner dan Jaqueline Vel, "An Analytical Framework for Empirical Research on Access to Justice," h. 10-19. 
Tabel 1. Steps to Justice menurut model Rolax

\begin{tabular}{|c|c|c|c|}
\hline No & Fase & Keterangan & Contoh \\
\hline 1. & Naming & $\begin{array}{l}\text { Seseorang mengalami situasi } \\
\text { ketidakadilan tertentu berupa perlakuan } \\
\text { tidak adil dan ia merasa dan menyadari } \\
\text { akan perlakuan yang ia terima. Sikap } \\
\text { yang diambil tidak sekadar 'natural' } \\
\text { atau 'deserved' (menerima), tetapi harus } \\
\text { dapat menjelaskan masalah sebenarnya } \\
\text { sebagai bentuk ketidakadilan. }\end{array}$ & $\begin{array}{l}\text { Setelah sekian tahun bersosialisasi } \\
\text { dan mengetahui kondisi temannya, } \\
\text { seorang buruh miskin yang } \\
\text { dieksploitasi oleh seorang majikan } \\
\text { misalnya menyadari kesulitan } \\
\text { untuk mendefinisikan bahwa upah } \\
\text { yang diterimanya terlalu rendah } \\
\text { atau aturan kerja yang sangat berat } \\
\text { adalah sebuah persoalan yang harus } \\
\text { dicarikan jalan keluarnya. }\end{array}$ \\
\hline 2. & Blaming & $\begin{array}{l}\text { Posisi seseorang saat mereka memiliki } \\
\text { kesadaran bahwa ketidakadilan yang } \\
\text { mereka alami merupakan akibat dari } \\
\text { perbuatan seseorang lain dan dapat } \\
\text { merumuskan keluhannya. Pada posisi } \\
\text { ini, ia memiliki keberanian sikap untuk } \\
\text { menuntut orang atau pihak yang } \\
\text { melakukan kekerasan terhadapnya. }\end{array}$ & $\begin{array}{l}\text { Seorang petani (nelayan) udang } \\
\text { menyadari bahwa merosotnya } \\
\text { hasil produksi udang bukan faktor } \\
\text { kebetulan, tetapi karena populasi } \\
\text { yang dihasilkan oleh pabrik minyak. }\end{array}$ \\
\hline 3 & Claiming & $\begin{array}{l}\text { Pencari keadilan memiliki kemampuan } \\
\text { untuk mengungkapkan persoalan dan } \\
\text { merumuskan gugatan dalam kerangka } \\
\text { normatif dan mekanisme hukum } \\
\text { tertentu (adat, negara, dan Islam) dan } \\
\text { mampu menuntut adanya pemulihan } \\
\text { atas kerugian yang diterima. }\end{array}$ & $\begin{array}{l}\text { Seorang pekerja yang dipecat } \\
\text { dari sebuah perusahaan memiliki } \\
\text { pengetahuan tentang hukum tenaga } \\
\text { kerja bahwa pemutusan hubungan } \\
\text { kerjanya tidak legal dan, karena itu, } \\
\text { perusahaan dapat dikenakan sanksi. }\end{array}$ \\
\hline 4 & $\begin{array}{l}\text { Accessing a } \\
\text { Forum }\end{array}$ & $\begin{array}{l}\text { Pencari keadilan melaporkan } \\
\text { tuntutan/gugatannya kepada pihak } \\
\text { yang berwenang, seperti pengadilan, } \\
\text { lembaga adat, atau kepala desa, } \\
\text { yang dapat membantunya untuk } \\
\text { mendapatkan pemulihan (remedy) hak. }\end{array}$ & $\begin{array}{l}\text { Pekerja migran yang bekerja sebagai } \\
\text { TKI di luar negeri mendapati kesulitan } \\
\text { untuk melaporkan penyimpangan dan } \\
\text { eksploitas yang mereka timpa karena } \\
\text { ketidaktahuan mereka atas di mana } \\
\text { dan ke mana harus melapor (sistem/ } \\
\text { tata cara pengaduan). }\end{array}$ \\
\hline 5 & Handling & $\begin{array}{l}\text { Pihak (forum) berwenang yang } \\
\text { dipilih menyidangkan persoalan } \\
\text { dengan menerapkan aturan hukum } \\
\text { secara adil tanpa memihak, tepat } \\
\text { waktu, dan konsisten. }\end{array}$ & \\
\hline 6 & Enforcing & $\begin{array}{l}\text { Pencari keadilan mendapatkan } \\
\text { jawaban (kepastian hukum) terhadap } \\
\text { tuntutan/gugatannya karena putusan } \\
\text { (pengadilan, lembaga adat, dan } \\
\text { otoritas lainnya) telah dilaksanakan. }\end{array}$ & $\begin{array}{l}\text { Meskipun hakim pengadilan agama } \\
\text { sudah memasukkan nafkah setelah } \\
\text { perceraian harus dipenuhi oleh mantan } \\
\text { suami, isteri seringkali mendapatkan } \\
\text { kesulitan untuk mendapatkan nafkah } \\
\text { tersebut dari bekas suaminya. }\end{array}$ \\
\hline
\end{tabular}


Jika melihat tabel pentahapan tercapainya keadilan hukum di atas, sidang keliling menempati tahap keempat, accessing a forum. Sidang keliling merupakan wadah dan instrumen bantuan hukum yang diberikan oleh negara agar masyarakat semakin mendapat kemudahan dalam mendapatkan solusi hukum atas persoalan ketidakadilan yang mereka alami. Pertanyaannya kemudian sejauhmana sidang keliling benar-benar menjawab persoalan akses masyarakat miskin di pedesaan terhadap keadilan.

\section{Sidang Keliling di PA Wonogiri}

Wonogiri merupakan salah satu daerah di Jawa tengah, terkenal dengan wisata waduk Gajah Mungkur, yang terletak di bagian selatan Pulau Jawa yang berbatasan dengan tiga kabupaten di Jawa Timur; Ponorogo dan Magetan di sebelah Timur dan Pacitan di sebelah Selatan. Alamnya sebagian besar didominasi oleh pegunungan berbatu gamping. Berdasarkan data dari Dinas Kependudukan dan Catatan Sipil Kabupaten Wonogiri, jumlah penduduk Kabupaten Wonogiri pada tahun 2011 mencapai 1.252.930 jiwa dengan komposisi 629.432 penduduk laki-laki dan 623.498 jiwa penduduk perempuan dan laju pertumbuhan penduduk 0,56\%. Di bidang ekonomi, Wonogiri menunjukkan perkembangan yang menggembirakan. Perkembangan pendapatan per kapita di Wonogiri atas dasar harga berlaku menunjukkan adanya peningkatan dari tahun ke tahun. ${ }^{21}$

Meningkatnya perekenomian dan tingkat pengetahuan masyarakat Wonogiri di bidang hukum, terutama perempuan, berimbas pada meningkatnya jumlah perkara perdata keluarga yang diajukan ke PA Wonogiri. Tentu, lebih dari $80 \%$ perkara yang diajukan adalah kasus perceraian. Dari semua perkara perceraian, lebih dari 50\% merupakan cerai gugat (pihak istri yang menggugat cerai suaminya). Meningkatnya pemahaman dan kesadaran perempuan terhadap hak-hak isteri dalam rumah tangga diyakini menjadi penyumbang tingginya angka gugat cerai. Di tahun 2012, permohonan perceraian tercatat mencapai 1.837 perkara, sedangkan di tahun 2011 sebanyak 1.623 perkara.

${ }^{21}$ Data diolah dari Informasi Laporan Penyelenggaraan Pemerintahan Daerah (ILPPD) Kabupaten Wonogiri Tahun 2011. 
Menurut salah satu hakim, hampir sebagian besar faktor keretakan rumah tangga di Wonogiri disebabkan adanya pihak ketiga yang masuk ke dalam rumah tangga. Biasanya, kasus bermula dari suami yang merantau untuk meningkatkan ekonomi keluarga. Saat di tempat yang baru, ada orang ketiga yang datang dan menganggu rumah tangga mereka. Kemiskinan dan rendahnya kesejahteraan keluarga ternyata bukan lagi menjadi alasan permohonan atau gugatan cerai. Jika merujuk data perceraian di wilayah yuridiksi Semarang, dari 58.022 kasus perceraian yang diajukan, tidak adanya tanggungjawab menjadi faktor terbesar (24.379), berikutnya faktor ekonomi (11.9390) dan tidak adanya keharmonisan (15.645). ${ }^{22}$

Memperhatikan besarnya jumlah perkara yang diajukan dan posisi beberapa daerah yang jauh dari pusat kota, PA Wonogiri menyelenggarakan sidang di luar tempat sidang (zitting plaatz). Dengan demikian, para pencari keadilan yang sebelumnya memiliki kendala dan keterbatasan untuk mengakses pengadilan, sekarang relatif terbantu. Sidang keliling di PA Wonogiri dilaksanakan berdasarkan SuratKeputusan Ketua PA Wonogiri 27 Pebruari 2012 No. W11.A.26/692/Hk.03.5/I/2012 tentang penyelenggaraan sidang keliling di Wilayah Kabupaten Wonogiri yang diselenggarakan di Kantor Kecamatan Purwantoro Jl. Raya Purwantoro, Wonogiri dan di Kantor Kecamatan Baturetno Jl. Raya Baturetno, Wonogiri. Untuk tahun 2013, karena keterbatasan anggaran DIPA, sidang keliling hanya dilaksanakan di Kecamatan Baturetno.

\section{Pelaksanaan Sidang Keliling}

Pada tahun 2012, PA Wonogiri menyelenggarakan sidang keliling di dua wilayah yang secara gerografis jaraknya jauh dari pengadilan, yaitu di Baturetno dan Purwantoro. Jarak Baturetno ke PA Wonogiri sekitar $35 \mathrm{~km}$, sedangkan Purwantoro ke PA. Waktu tempuh yang dibutuhkan untuk mencapai PA Wonogiri adalah 1,5 jam untuk Purwantoro dan 1 jam untuk Baturetno. Jauhnya jarak dan lamanya waktu tempuh inilah yang menjadi alasan pemilihan lokasi sidang keliling. ${ }^{23}$

\footnotetext{
22 Rekap Faktor Perceraian tahun 2011.

${ }^{23}$ Wawancara dengan Djuminah, Sekretaris/Panitera, Agustus 2013.
} 
Seperti layaknya proses pelaksanaan sidang di pengadilan, mekanisme pelaksanaan sidang keliling juga melalui tahapan-tahapan sebagaimana diatur dalam hukum acara Pengadilan Agama. Tidak ada pembedaan prosedur berperkara untuk sidang di pengadilan dan sidang keliling. Perbedaan yang paling signifikan adalah hanya pada tempat pelaksanaan sidang. Berikut paparan dari Ketua PA Wonogiri tentang sidang keliling: ${ }^{24}$

"Proses berperkara di Pengadilan Agama Wonogiri melalui sidang keliling ini sama seperti layaknya berperkara melalui sidang biasa. Tempat pelaksanaan sidang keliling ini diprioritaskan di daerah yang jaraknya jauh dari Pengadilan Agama setempat. Pendaftaran perkara tetap dilakukan di kantor pengadilan. Dilakukan di luar pengadilan hanya sidangnya."

Informasi dari hakim yang lain juga menegaskan bahwa teknis sidang keliling sama halnya dengan sidang biasa pada umumnya. Inti dari pelaksanaan sidang keliling adalah membantu masyarakat yang kurang/ tidak mampu khususnya yang rumah tinggalnya jauh dari pengadilan. Berikut penuturannya: ${ }^{25}$

"Untuk teknis pelaksanaan sama seperti sidang biasanya, dari proses pendaftaran, hingga putusan. Pembedanya adalah misi dilaksanakannya sidang keliling yaitu untuk membantu masyarakat miskin supaya tidak banyak mengeluarkan uang dan lokasi sidangnya berada di luar kantor pengadilan.”

Pendapat kedua hakim memberi gambaran yang cukup jelas bahwa sidang keliling hanya persoalan teknis memindah tempat sidang, dari kantor pengadilan ke tempat lain di luar pengadilan. Ini berarti pendaftaran dan proses lain selain persidangan harus dilakukan di kantor pengadilan. Para pihak yang perkaranya terpilih diselesaikan melalui sidang keliling juga harus membayar panjar biaya perkara.Ini didasarkan pada salah satu asas bahwa pada dasarnya mengajukan gugatan atau permohonan ke pengadilan harus dengan membayar biaya perkara.

Sidang keliling di PA Wonogiri dilaksanakan setiap hari Jum'at selama beberapa Minggu yang telah ditentukan di dua wilayah, Baturetno dan Purwantoro. Dua wilayah ini juga mencakup beberapa wilayah yang dekat di sekitarnya. Pembagian zona kecamatan pelaksanaan sidang

${ }^{24}$ Wawancara dengan Zainal Arifin, Ketua PA Wonogiri, 2013.

${ }^{25}$ Wawancara dengan Nurul Aziz SI, Hakim, September 2013. 
keliling adalah sebagai berikut:

a. Komplek Kecamatan Purwantoro meliputi Kecamatan Slogohimo, Kecamatan Purwantoro, Kecamatan Kismantoro, Kecamatan Bulukerto, dan Kecamatan Puh Pelem.

b. Komplek Kecamatan Baturetno meliputi Kecamatan Tirtomoyo, Kecamatan Baturetno, Kecamatan Batuwarno, Kecamatan Giritontro, Kecamatan Giriwoyo, Kecamatan Karangtengah, dan Kecamatan Paranggupito

\section{Perkara dan Pengguna}

Jumlah perkara di PA Wonogiri, terutama perceraian, dari tahun ke tahun mengalami peningkatan. Pada tahun 2012, jumlah perkara yang diputus sebanyak 1736 perkara. Perkara yang terbanyak adalah gugat cerai, diikuti perkara cerai talak. Pada tahun 2010, terdapat 379 perkara cerai talak dan 938 perkara cerai gugat yang telah diputus. Pada tahun 2011, jumlah perkara cerai talak sebanyak 428 sedangkan cerai gugat 1074 perkara. Tahun 2012 mengalami peningkatan lagi, yaitu 526 untuk perkara cerai talak dan 1165 untuk perkara cerai gugat.

Perbandingan besarnya jumlah perkara yang diputus dengan jumlah perkara yang disidangkan melalui sidang keliling memang sangat tidak seimbang. Tabel berikut menjelaskan secara rinci jumlah perkara sidang keliling pada tahun 2012 di dua wilayah.

\begin{tabular}{clcccc}
\hline \multirow{2}{*}{ No. } & \multirow{2}{*}{ Jenis Perkara } & \multicolumn{2}{c}{ Purwantoro } & \multicolumn{2}{c}{ Baturetno } \\
\cline { 3 - 6 } & $\begin{array}{c}\text { Perkara } \\
\text { Diperiksa }\end{array}$ & $\begin{array}{c}\text { Perkara } \\
\text { Diputus }\end{array}$ & $\begin{array}{c}\text { Perkara } \\
\text { Diperiksa }\end{array}$ & $\begin{array}{c}\text { Perkara } \\
\text { Diputus }\end{array}$ \\
\hline 1. & Cerai Gugat & 57 & 27 & 79 & 34 \\
\hline 2. & Cerai Talak & 36 & 13 & 60 & 15 \\
\hline 3. & Lain-lain & 11 & 6 & 12 & 9 \\
\hline & Jumlah & 104 & 46 & 151 & 58 \\
\hline
\end{tabular}

Pada tahun 2013, karena sidang keliling hanya dilakukan di satu tempat, yaitu di Baturetno jumlah perkara yang diputus dalam sidang keliling sebanyak hanya 35 perkara dengan perincian sebagai berikut: 11 perkara cerai talak, 19 perkara cerai gugat, 2 perkara isbat nikah, dan 3 perkara dispensasi kawin. 
Untuk melihat bagaimana persepsi para pihak pada perkara sidang keliling, peneliti melakukan wawancara terhadap beberapa orang. Secara umum, sebelumnya mereka tidak mengetahui jika ada sidang keliling. Sejak awal sebelum mendaftarkan perkara di PA, mereka juga sudah sudah siap jika harus pergi ke kantor pengadilan untuk menyelesaikan perkaranya. Mereka juga siap untuk membayar panjar biaya perkara. SR (26 tahun) misalnya mengungkapkan bahwa pelaksanaan sidang di Kecamatan Baturetno merupakan sidang kedua untuk perkara gugat cerainya. Pada saat mendaftar dia tidak mengetahui jika ada layanan sidang keliling. Dirinya baru mengetahuinya setelah mendapatkan surat panggilan sidang (relaas) yang menyatakan bahwa tempat sidang tidak di kantor pengadilan, tetapi di kantor kecamatan Baturetno. Tentu, dirinya merasa terbantu karena sidang di kantor kecamatan lebih dekat dan terjangkau daripada di pengadilan yang membutuhkan kurang lebih dua jam jika ditempuh dengan kendaraan umum. ${ }^{26}$

Sama halnya dengan SR, RI (35 tahun) mengafirmasi bahwa informasi penyelenggaraan sidang keliling baru diterima setelah menerima surat panggilan sidang. Karena lokasi rumahnya di Desa Selopuro, Batuwarno, dirinya tentu merasa senang lebih dekat dengan rumahnya. Selain itu, proses persidangan juga tidak dipersulit dikarenakan perkara gugat cerai yang ia ajukan sudah dikabulkan dengan putusan verstek. ${ }^{27}$

Informan lain yang perkaranya diperiksa melalui sidang keliling justeru tidak menyoal tentang HRA yang menyatakan bahwa sidang di Kantor Kecamatan Baturetno adalah sidang kedua untuk perkara gugatan cerainya. Baginya, tidak menjadi soal apakah sidang dilaksanakan di kantor pengadilan atau di lokasi sidang keliling. Menurutnya, yang penting dari semua proses yang dia jalani adalah bahwa adalah perkara yang diajukan cepat selesai. Tentu saja, jika diminta memilih, sidang di kantor kecamatan lebih memudahkan selain karena jarak dari rumah lebih dekat dan antrian untuk sidang tidak sebanyak dengan yang ada di kantor pengadilan. ${ }^{28}$

\footnotetext{
26 Wawancara dengan SR, Juli 2013.

27 Wawancara dengan RI, Juli 2013.

28 Wawancara dengan HRA, Juli 2013.
} 


\section{Peran Sidang Keliling dalam Penguatan Akses terhadap Keadilan}

Persoalan sidang keliling selalu dikaitkan dengan asas pemberian bantuan hukum sebagaimana diatur dalam pasal 58 ayat (2) UU No. 50/ 2009 jo. Pasal 5 ayat (2) UU No. 48/2009 tentang Kekuasaan Kehakiman yang berbunyi: "Pengadilan membantu para pencari keadilan dan berusaha sekeras-kerasnya mengatasi segala hambatan dan rintangan untuk tercapainya peradilan yang sederhana, cepat, dan biaya ringan."

Pelaksanaan sidang keliling di PA Wonogiri juga didasarkan pada pasal 28 ayat (1) Undang-Undang Dasar 1945 yang menyatakan dengan tegas bahwa setiap orang berhak atas pengakuan, jaminan, perlindungan dan kepastian hukum yang adil serta perlakuan yang sama dihadapan hukum. Selain itu, landasan hukum yang dipakai adalah pasal 56 ayat (1) UU No48 tahun 2009 tentang Kekuasaan Kehakiman dan pasal 60B ayat (1) Undang-Undang No50 tahun 2009 menyebutkan bahwa "setiap orang yang tersangkut perkara berhak menerima bantuan hukum.” Terkait ketentuan teknis penyelenggaran sidang keliling, pasal 10-15 SEMA Nomor 10 Tahun 2010 Tentang Pedoman Pemberian Bantuan Hukum di Lingkungan Peradilan Agama yang menyebutkan tentang penyelenggaraan sidang keliling, lokasi sidang keliling, petugas pelaksanaan sidang keliling, biaya penyelenggaraan sidang keliling, mekanisme pengawasan dan pertanggungjawaban serta ketentuan lain. ${ }^{29}$

Pertimbangan PA Wonogiri dalam melaksanakan sidang keliling di Komplek Kecamatan Purwantoro dan Komplek Kecamatan Baturetno adalah karena kedua lokasi tersebut merupakan lokasi yang paling jauh dari PA Wonogiri. Kecamatan Purwantoro berbatasan dengan Kabupaten Ponorogo dan Kecamatan Baturetno berbatasan dengan Kabupaten Pacitan. Selain itu, karena kedua lokasi tersebut dekat dengan beberapa kecamatan yang termasuk ke dalam wilayah sulit/radius khusus PA Wonogiri sehingga bisa menjangkau beberapa kecamatan. ${ }^{30}$

Jika dilihat dari SEMA No. 10 Tahun 2010 Lampiran B pasal 11 ayat (1) yang menyebutkan bahwa sidang keliling dilaksanakan di lokasi yang jauh

\footnotetext{
29 Wawancara dengan Faisol Chadid, Hakim di PA Wonogiri, September 2013.

${ }^{30}$ Wawancara dengan Djuminah, Sekretaris/Panitera, September 2013.
} 
dari Kantor Pengadilan Agama atau di lokasi yang menyulitkan para pencari keadilan baik dari segi biaya, transportasi, maupun proses apabila sidang dilaksanakan di Kantor Pengadilan, maka penyelengaraan sidang keliling oleh PA Wonogiri sudah sesuai dengan kaidah yang ada. Penyelenggaraan sidang keliling di kantor Kecamatan juga sudah sesuai dengan aturan yang tercantum di dalam SEMA No. 10/2010 pasal 11 ayat (2).

Sidang keliling bertujuan memberikan pelayanan yang prima kepada masyarakat pencari keadilan dengan memberikan kemudahan seperti tempat pelaksanaan sidang yang lebih dekat dengan tempat tinggal para pihak, biaya transportasi lebih ringan dan menghemat waktu. ${ }^{31}$ Manfaat dari sidang keliling bagi PA Wonogiri adalah mempermudah mereka untuk mengetahui daerah hukumnya, mengurangi tumpukan perkara dan bisa menerapkan beberapa asas, yaitu peradilan sederhana, cepat, dan biaya ringan, mengadili menurut hukum dan persamaan hak, dan pemberian bantuan hukum.

Berdasar penjelasan tentang pelaksanaan sidang keliling oleh PA Wonogiri di atas, maka dapat ditarik satu kesimpulan bahwa sidang keliling yang dilakukan oleh PA Wonogiri sudah memenuhi mekanisme dan prosedur yang ada, termasuk hukum acara. Para pihak yang perkaranya disidangkan di sidang keliling juga mengafirmasibahwa sidang kelilingyang pelaksanaannya lebih dekat dengan tempat tinggal para pihak dapat menekan biaya transportasi dan menghemat waktu. Bagi para pihak yang memiliki kehidupan ekonomi pada arus bawah, tentu sidang keliling ini sangat bermakna. Dengan nalar ini, program sidang keliling dapat dikatakan berjalan dengan efektif dan sesuai dengan konsep sebagaimana yang termuat dalam sejumlah aturan yang berlaku.

Persoalan berikutnya yang sesungguhnya lebih penting dijawab adalah sejauh mana sidang keliling tersebut telah memberi kontribusi terhadap penguatan terhadap akses keadilan? Apakah sidang keliling telah menjawab persoalan beberapa elemen masyarakat yang selama ini sama sekali tidak memiliki akses untuk mendapatkan keadilan melalui

${ }^{31} \mathrm{Hal}$ ini berpedoman pada salah satu tujuan bantuan hukum yang tertera di dalam SEMA No. 10 Tahun 2010 pasal 2 ayat (4) yang menyebutkan bahwa "bantuan hukum bertujuan untuk memberikan pelayanan prima kepada masyarakat pencari keadilan." 
pranata peradilan? Bagaimana dengan sebagian masyarakat yang bahkan untuk mendaftarkan perkaranya ke pengadilan saja tidak punya kuasa?

Jika diuji dengan teori pentahapan akses terhadap keadilan model Rolax yang peneliti telah sederhanakan dapat dijelaskan dalam narasi sebagai berikut:

\section{Naming, blaming, dan claiming}

Sebagian besar perkara yang diajukan adalah kasus perceraian. Dalam hal ini, data jumlah perkara gugat cerai di PA Wonogiri yang lebih besar dibanding cerai talak secara jelas menunjukkan bahwa perempuan semakin memiliki kekuatan dan kapasitas untuk menyelesaikan persoalan keluarga yang mereka hadapi dan untuk mendapatkan keadilan melalui mekanisme negara.

\section{Accessing a forum}

Merujuk hasil wawancara dengan beberapa pihak pada perkara sidang keliling di atas, kesediaan mereka untuk mendaftarkan perkaranya di kantor pengadilan serta membayar panjar biaya perkara menunjukkan bahwa ada dan tidak adanya sidang keliling hanya sekedar membantu dari sisi efisiensi waktu dan biaya transportasi yang dikeluarkan. Motifasi mereka untuk mendapatkan kepastian bahwa perkara yang diajukan cepat selesai jauh lebih penting daripada sidang keliling.

Di sini, pentingnya peningkatakan sosialiasi tentang sidang keliling terhadap masyarakat yang lebih luas dan peningkatan layanan yang lain, misal semua proses berperkara dari mulai pendaftaran perkara sampai putusan dapat dilakukan di luar kantor pengadilan. Di dalam petunjuk pelaksanaan sidang keliling yang dikeluarkan oleh MA pada pasal 6 ayat (6) dan (8) menyebutkan bahwa pelaksanaan mediasi serta pendaftaran perkara baru dapat dapat dilakukan di lokasi sidang keliling. ${ }^{32}$ Tentu, pelaksanaannya tetap berpedoman pada peraturan dan hukum acara yang berlaku, seperti peraturan

32 "Keputusan Ketua Muda Urusan Lingkungan Peradilan Agama dan Sekretaris Mahkamah Agung RI Nomor: 04/TUADA-AG/11/2011 Tentang Petunjuk Pelaksanaan Surat Edaran Mahkamah Agung RI Nomor 10 Tahun 2010 Tentang Pedoman Bantuan Hukum lampiran B”. 
MA tentang Prosedur Mediasi. ${ }^{33}$ Jika ini dapat dilakukan, maka penguatan akses terhadap keadilan bagi masyarakat lemah benarbenar dapat dijawab melalui sidang keliling.

Pada tahap ini, dapat dikatakan bahwa sidang keliling sebagai jawaban terhadap lemahnya akses masyarakat terhadap keadilan masih belum jelas relevansinya.

3. Handling dan Enforcing

Jika tahap 'akses terhadap peradilan' sudah terpenuhi dengan optimal, maka dua tahap ini akan secara otomatis mengikuti.

Perluasan pemenuhan dan akses terhadap keadilan (access to justice) bagi Pengadilan Agama menjadi sangat penting sebab jika dilaksanakan secara maksimal dan konsisten dapat berdampak positif terhadap masyarakat miskin dan terpinggirkan dengan hasil adanya kepastian hukum berupa dokumentasi (putusan/penetapan) dalam bidang perkawinan dan perceraian, akta kelahiran bagi anak-anak yang mereka lahirkan, sehingga memberikan kepastian pada hak warisan anak dan akses pada pelayanan pemerintah seperti sekolah negeri dan layanan kesehatan sehingga akan meningkatkan kepercayaan masyarakat terhadap negara dan aturan hukum yang ada. Di samping itu juga dapat berdampak positif terhadap peningkatan kesejahteraan rakyat dan penguatan tata kelola pemerintahan yang demokratis (democratic governance).

\section{Penutup}

Berdasar data dan analisis di atas, penelitian ini menyimpulkan bahwa penyelesaian perkara melalui sidang keliling, sebagai bagian dari bantuan hukum, di PA Wonogiri telah diselenggarakan sesuai aturan yang ditetapkan baik dalam pasal 60C (1) UU No. 50/2009, pasal 57 (1) UU No. 48/2009, dan SEMA No. 10/2010 serta hukum acara yang berlaku di Pengadilan Agama. Para pihak yang berperkara baru mengetahui jika perkaranya diperiksa melalui sidang keliling setelah mereka menerima surat panggilan untuk menghadiri (relaas). Pemilihan perkara siapa

33 "PERMA No. 1 tahun 2008 tentang Prosedur Mediasi". 
yang diproses melalui sidang keliling hanya didasarkan pada kedekatan jarak para pihak dengan lokasi sidang keliling. Aspek kemampuan atau ketidakmampuan (secara ekonomi) dalam mengakses keadilan melalui peradilan belum menjadi pertimbangan yang penting.

Berdasar dua temuan di atas, sidang keliling memang memiliki peran yang relatif penting dalam peningkatan akses masyarakat, terutama perempuan, terhadap keadilan. Karena semua pengguna sidang keliling ini adalah mereka yang sejak awal siap untuk bersidang di kantor pengadilan, penguatan akses ini lebih dimaknai sebagai upaya memberi bantuan kepada para pihak agar waktu, biaya, dan tenaga yang mereka luangkan untuk menghadiri sidang lebih efisien. Karena itu, jika dilihat dari substansi dan tujuan 'akses terhadap keadilan', pelaksanaan sidang keliling belum optimal. Fungsi sidang keliling belum dapat dirasakan masyarakat yang sama sekali tidak memiliki akses ke pengadilan.

\section{Pustaka Acuan}

Arijaya, Rahmat. "Access to Justice for Women: The Role of the Religious Courts”, paper disampaikan pada the Sixth Badilag's English Meeting Club, 28 Juni 2010.

Azizah, Ulfi. "Analisis Hukum Acara Pelaksanaan Sidang Keliling (Studi Kasus Sidang Keliling di Pengadilan Agama Mungkid).” PhD diss., IAIN Walisongo, 2013.

Basuki, Ahmad. "Pengawasan Terhadap Penyelenggaraan Kekuasaan Kehakiman Sebagai Upaya dalam Mewujudkan Akuntabilitas Peradilan Pidana." Perspektif 18, no. 1 (2013): 56-63.

Bedner, Adriaan. "An Elementary Approach to the Rule of Law," Hague Journal on the Rule of Law 2, (2010). , and Jaqueline Vel. "An Analytical Framework for Empirical Research on Access to Justice”. Law, Social Justice \& Global Development (An Electronic Law Journal), 1, (2010).

Ward Berenschot, Eddie Riyadi Laggut-Terre, dan Dewi Novirianti. "Akses Terhadap Keadilan: Perjuangan Masyarakat Miskin dan Kurang Beruntung Untuk Menuntut Hak di Indonesia." Jakarta: HuMa-Jakarta, Van Vollenhoven Institute, Leiden University, KITLV- 
Jakarta: Epistema Institute (2011).

Cahyadi, Thalis Noor. "Efektifitas Pos Bantuan Hukum di Pengadilan (Studi Pada Posbakum Pengadilan Agama Sleman Tahun 20112012)." Jurnal Rechts Vinding: Media Pembinaan Hukum Nasional 2, no. 1 (2013): 17-30.

Berenschot, Ward dan Adriaan Bedner, "Akses Terhadap Keadilan: An Introduction to Indonesia's Struggle to Make the Law Work for Everyone", paper diterbitkan online oleh KITLV, Belanda. , Adriaan Bedner, E. Laggut-Terre, dan D. Novrianti. "Akses

Terhadap Keadilan: Perjuangan Masyarakat Miskin dan Kurang Beruntung Untuk Menuntut Hak di Indonesia.” (2011).

Chamanda, Muh. "Efektifitas Sidang Keliling Kaitannya dengan Asas Sederhana, Cepat, dan Biaya Ringan (Studi Kasus di Pengadilan Agama Sungguminasa Kelas 2B Tahun 2013-2015).” PhD diss., Universitas Islam Negeri Alauddin Makassar, 2016.

Denzin, Norman K. \& Lincoln, Yvonna S. Handbook of Qualitative Research. Yogyakarta: Pustaka Pelajar, 2009.

Endarwati, Endarwati. "Gugatan Cerai dengan Alasan Menolak Dipoligami (Studi Kasus di Pengadilan Agama Wonogiri)." PhD diss., Universitas Muhammadiyah Surakarta, 2008.

Farbenblum, Bassina, Eleanor Taylor-Nicholson, dan Sarah Paoletti. Akses Buruh Migran Terhadap Keadilan di Negara Asal: Studi Kasus di Indonesia. Open Society Foundations, 2013.

Firdaus, Desy Meutia. "Reorientasi Konsep Kekuasaan Kehakiman dan Implikasinya Terhadap Kedudukan Mahkamah Agung dalam Sistem Peradilan Pidana di Indonesia." PhD diss., Program Pasca Sarjana Universitas Diponegoro, 2001.

Fernanda, Desi. "Paradigma New Public Management (NPM) Sebagai Kerangka Reformasi Birokrasi Menuju Kepemerintahan yang Baik (Good Governance) di Indonesia." Jurnal Borneo Administrator 2, no. 3 (2006).

Gaffar, Janedjri M. "Kedudukan, Fungsi dan Peran Mahkamah Konstitusi dalam Sistem Ketatanegaraan Republik Indonesia." Jurnal Mahkamah Konstitusi, Jakarta (2009). 
Hasan, Hasbi. "Dinamika Yurisprudensi Mahkamah Agung dalam Bidang Perdata Islam." Journal de Jure 3, no. 2 (2011).

Hartatik, Sofiani. "Analisis Yuridis Terhadap Pelaksanaan Sidang Keliling Itsbat Nikah: Studi Kasus Pengadilan Agama Kabupaten Malang." PhD diss., UIN Sunan Ampel Surabaya, 2014.

Irianto, Sulistyowati. Perempuan dan Hukum: Menuju Hukum yang Berperspektif Kesetaraan dan Keadilan: 22 Tahun Konvensi CEDAW di Indonesia. Yayasan Obor Indonesia, 2006.

, Henky Irzan, Lim Sing Meij, Theresia Dyah Wirastri, Tirtawening Parikesit, Titiek Kartika, dan Vidhyandika D. Perkasa. Akses Keadilan dan Migrasi Global: Kisah Perempuan Indonesia Pekerja Domestik di Uni Emirat Arab. Yayasan Pustaka Obor Indonesia, 2011.

Kamaruddin. "Diskursus Penyatuatapan Peradilan Agama di Bawah Mahkamah Agung (Studi Hukum Responsif)." Al-'Adl 8, no. 1 (2015): 56-72.

Kelompok Kerja Akses terhadap Keadilan. Strategi Nasional Akses terhadap Keadilan. Jakarta: Kementerian Bappenas, 2009.

Keputusan Ketua Muda Urusan Lingkungan Peradilan Agama dan Sekretaris Mahkamah Agung RI Nomor: 04/TUADA-AG/11/2011 Tentang Petunjuk Pelaksanaan Surat Edaran Mahkamah Agung RI Nomor 10 Tahun 2010 Tentang Pedoman Bantuan Hukum lampiran B.

Khisni, H.A. "Peradilan Agama Sebagai Peradilan Keluarga Serta Perkembangan Studi Hukum Islam di Indonesia”, Jurnal Hukum Universitas Sultan Agung 15, No. 1, (April 2011).

Kusmayanti, Hazar, Eidy Sandra, dan Ria Novianti. "Sidang Keliling dan Prinsip-Prinsip Hukum Acara Perdata: Studi Pengamatan Sidang Keliling di Pengadilan Agama Tasikmalaya." Jurnal Hukum Acara Perdata ADHAPER 1, no. 2 (2015): 101-116.

Kurniawan, Anggit. "Tinjauan Yuridis Dispensasi Permohonan Nikah Bagi Anak di Bawah Umur (Studi Kasus Penetapan Pengadilan Agama Wonogiri).” PhD diss., Universitas Muhammadiyah Surakarta, 2014. Lakburlawal, Mahrita Aprilya. "Akses Keadilan Bagi Masyarakat Adat dalam Penyelesaian Sengketa Tanah Ulayat yang Diberikan Hak 
Guna Usaha." Jurnal Hukum Acara Perdata ADHAPER 2, no. 1 (2016): 59-75.

Lindsey, Tim dan Cute Sumner. "Indonesia: Islamic Courts as Governance Institutions" dalam East Asia Forum Quarterly 3, No 1 (JanuariMaret 2011).

Mahkamah Agung. Cetak Biru Pembaruan Peradilan 2010-2035. Jakarta: MA RI, 2010.

Mafazatin, Arina El Haque. "Analisis Hukum Islam Terhadap Permohonan Talak Sebab Murtad (Telaah Putusan Pengadilan Agama Wonogiri Nomor: 0080/Pdt. G/2013/PA. Wng dan Nomor: 0838/Pdt. G/2009/PA. Wng).” PhD diss., UIN Walisongo, 2014.

Malinda, Anggung, Eka Nur Fitriana, dan M. Yasin al Arif. "Bantuan Hukum Terhadap Kaum Difabel Korban Tindak Pidana Upaya Mewujudkan Acces to Justice”. Jurnal Hukum Ius Quia Iustum 21, No. 3, (Juli 2014).

Moleong, Lexy J. Metodologi Penelitian Kualitatif. Bandung: PT Remaja Rosdakarya, 2005.

Mulyaningsih, Ekawati. "Pertimbangan Hakim dalam Pemberian Izin Poligami Menurut Undang-Undang Nomor 1 Tahun 1974 Tentang Perkawinan dan Peraturan Pemerintah Nomor 9 tahun 1975 Tentang Pelaksanaan Undang-Undang Perkawinan di Pengadilan Agama Wonogiri (Studi Kasus Perkara Nomor 515/pdt. g/2000/pa. wng).” PhD diss., Universitas Sebelas Maret, 2010.

Novirianti, Dewi. "Akses Perempuan terhadap Keadilan: Mekanisme Hukum dan Keadilan, Peranan Pendamping, dan Rasa Keadilan Korban", artikel dalam www.komnasperempuan.or.id (5 Januari 2011).

, "Female Migrant Workers and Access to Justice Case Study of District Legislation in Cianjur", working paper pada Van Vollenhoven Institute, 2009.

Nuswardani, Nunuk. "Upaya Peningkatan Kualitas Putusan Hakim Agung dalam Mewujudkan Law and Legal Reform.” Jurnal Hukum Ius Quia Iustum 16, no. 4 (2009): 515-532.

PA Wonogiri, Laporan Sidang Keling PA Wonogiri tahun 2011 dan 2012, dalam http://pa-wonogirikab.go.id/laporan/detail/sidang-keliling. 
PEKKA. Akses Perempuan terhadap Keadilan di Indonesia: Studi Kasus atas Perempuan Desa Pencari Keadilan di Cianjur, Brebes, dan Lombok. Jakarta: Justice for the Poor Project, 2008.

PERMA No. 1 tahun 2008 tentang Prosedur Mediasi.

Pompe, Sebastiaan. Runtuhnya Institusi Mahkamah Agung. Lembaga Kajian dan Advokasi untuk Independensi Peradilan, 2012.

Rekapitulasi Pelaporan dalam laman SMS Gateway Mahkamah Agung, http://sms.mahkamahagung.go.id/index.php/info/rekap.

Raharjo, Agus, A. Angkasa, dan Rahadi Wasi Bintoro. "Akses Keadilan Bagi Rakyat Miskin (Dilema dalam Pemberian Bantuan Hukum oleh Advokat)." Mimbar Hukum-Fakultas Hukum Universitas Gadjah Mada 27, no. 3 (2015): 432-444.

Rofi'i, Nor. "Analisis Hukum Acara Terhadap Pelaksanaan Sidang Keliling (Study Kasus Sidang Keliling di Pengadilan Agama Tanjung Balai Karimun di Kecamatan Kundur).” PhD diss., Universitas Islam Negeri Sultan Syarif Kasim Riau, 2015.

Syaefuddin, M. Amin. "Efektifitas Peran Sidang Keliling Terhadap Asas Sederhana, Cepat, dan Biaya Ringan di Pengadilan Agama Pasuruan tahun 2011.” PhD diss., Universitas Islam Negeri Maulana Malik Ibrahim, 2012.

SMERU Research Institute, "Akses terhadap Keadilan: Pemberdayaan Perempuan Kepala Keluarga di Indonesia (Studi Kasus di Provinsi Nanggroe Aceh Darussalam, Jawa Barat, Kalimantan Barat, dan Nusa Tenggara Timur)", Laporan Penelitian, Juli 2011.

Surat Edaran Mahkamah Agung No. 10/2010 tentang Pedoman Pemberian Bantuan Hukum.

Sumner, Cate. "Providing Justice for the Justice Seeker: A Report on the Indonesian Religious Courts, Access and Equality Study - 2007, Summary of Research Findings," survei oleh IALDF, UIN Jakarta dan Yogyakarta, PEKKA NGO, the Family Court of Australia, dan Mahkamah Agung. , dan Tim Lindsey. Courting Reform: Indonesia's Islamic Courts and Justice for the Poor. Australia: Lowy Institute for International Policy, 2010. 
Sugianto, Indro. Class Action: Konsep dan Strategi Gugatan Kelompok Untuk Membuka Akses Keadilan bagi Rakyat. Setara Press, 2013.

Sholikin, M. Nur. "Perbaikan Prosedur Pengujian Peraturan PerundangUndangan di Mahkamah Agung." Jurnal Hukum dan Peradilan 3, no. 2 (2014): 149-162.

UU No. UU 16/2011 tentang Bantuan Hukum

UU No. 50/ 2009 tentang Pengadilan Agama

UU No. 48/2009 tentang Kekuasaan Kehakiman

UNDP. Justice for All? An Assessment of Access to Justice in Five Provinces of Indonesia. Jakarta: UNDP, 2007.

Utama, Yos Johan. "Menggugat Fungsi Peradilan Tata Usaha Negara Sebagai Salah Satu Akses Warga Negara Untuk Mendapatkan Keadilan dalam Perkara Administrasi Negara." (2007).

Van Vollenhoven Institute, "The reseach scheme", diterbitkan di http:// law.leiden.edu/organisation/metajuridica/vvi/research/access-to-justice/ access-to-justice/the-concept.html.

Wahidin, Samsul. "Hakim Agung Sebagai Agent Of Change Menuju Law and Legal Reform." Jurnal Cakrawala Hukum 5, no. 2 (2014): 157-167.

\section{Wawancara}

Djuminah, Sekretaris/Panitera, Agustus 2013.

Zainal Arifin, Ketua PA Wonogiri, 2013.

Nurul Aziz SI, Hakim, September 2013.

SR, Juli 2013.

RI, Juli 2013.

HRA, Juli 2013.

Faisol Chadid, Hakim di PA Wonogiri, September 2013.

Djuminah, Sekretaris/Panitera, September 2013. 